DOI: 10.46340/eppd.2021.8.5.3

Kateryna Futorianska

ORCID ID: https://orcid.org/0000-0003-1735-1205

Taras Shevchenko National University of Kyiv, Ukraine

\title{
INTERIM MEASURES WITH RESPECT TO PERSONS IN DETENTION UNDER RULE 39 OF THE EUROPEAN COURT OF HUMAN RIGHTS
}

International human rights instruments are based on respect for human dignity, which also applies to the treatment of persons in detention. The European Court of Human Rights has stated in its case law that the State is obliged to organize its penitentiary system in such a way as to ensure respect for the dignity of detainees regardless of the existing financial and logistical constraints. However, practice has shown that there are multiple cases during detention where individuals may face violations of their rights, which in turn leads to the violation of generally accepted standards of detention.

Given the conditions of detention and the existing circumstances, the European Court of Human Rights may apply Rule 39 of the Rules of Court. Rule 39, which regulates the application of interim measures, makes it possible to respond in a timely manner to flagrant violations of human rights and freedoms guaranteed by the 1950 Convention for the Protection of Human Rights and Fundamental Freedoms and its relevant Protocols.

Clarifying the role of Rule 39 in the case of detainees is seen as a topical issue for the human rights agenda, as requests for interim measures are most often received by the ECtHR with regard to a violation of Article 3 of the Convention for the Protection of Human Rights and Fundamental Freedoms. To this end, the article examines the relevant case law of the ECtHR and shows that the Court may apply such interim measures to detainees, in particular, as ensuring appropriate conditions of detention, providing adequate medical care, ensuring access to legal representation and relatives, cessation of hunger strike, etc.

The article pays particular attention to the issue of further enforcement of Rules 39 of the Rules of Court, as practice has shown that such measures can not only substantially change the circumstances which the applicant finds themselves in, but also save and protect the person's life. In turn, the application of Rule 39 of the Rules of Court raises the question of the legal force of interim measures. As a result, the article examines the attitude of States to the approach adopted by the ECtHR - the existence of a close relationship between Rule 39 of the Rules of Court and Article 34 of the European Convention on Human Rights (individual applications). Failure to comply with Rule 39 of the Rules of Court may further be considered by the European Court of Human Rights as a violation of the European Convention on Human Rights, Article 3 in particular, which is likely to be reflected in the decision on the merits.

The study draws attention to the fact that the interim measures imposed on detainees invariably provide for a return to respect for human rights and fundamental freedoms. At the same time, a fair balance is needed between respect for the rights and freedoms of a detainee and the legal status of that person.

The case law of the European Court of Human Rights on interim measures has shown that States decide on the necessity of such measures at their own discretion, guided by their own interests the will of States is pivotal. Rule 39 of the Rules of Procedure, in turn, is used as a flag to States which emphasized the following aim - do not cross a red line in human rights dimension.

Keywords: European Court of Human Rights, Rule 39, interim measures, persons in detention, human rights.

Problem statement. Under basic principles for the treatment of persons in detention it is generally accepted that "all persons deprived of their liberty shall be treated with respect for their human 
rights"1. Moreover, the United Nations Standard Minimum Rules for the treatment of prisoners (the Nelson Mandela Rules) provide for that "the safety and security of prisoners, staff, service providers and visitors shall be ensured at all times"2 (Rule 1 of the Rules of general application). However, as practice demonstrates, there are widespread cases when persons deprived of their liberty face violations of their rights and situations in which they are subjected to treatment falling within the scope of the term "inhuman and degrading".

Taking into account the circumstances which a person in detention is under, the European Court of Human Rights may apply Rule 39 of the Rules of Procedure (interim measures). Interim measures are granted under the individual circumstances of each applicant and only in specific cases where a person has a real status of the victim - "there is an imminent risk of irreparable damage". In respect to persons in detention such measures are quite varied (providing appropriate conditions in detention, accessing health care and medical treatment, ending a hunger strike, providing the applicant with legal aid, stopping a death execution, releasing the applicant, etc.) The list of measures under Rule 39 in respect of persons in detention is not full and may be extended by the case practice of the European Court of Human Rights. However, the principal issue is further State's compliance with a decision on Rule 39 of the Rules of Procedure of the European Court of Human Rights since the case practice proves that such measures may not just fundamentally change the circumstances which an applicant is under, but even save his/her life.

Aim of the article. The article is aimed at analyzing the role of interim measures in cases of persons in detention, particularly, if an applicant faces inadmissible conditions during his/her imprisonment and there is a risk for his/her life and health status. Taking into account that there is no full list of interim measures which may be indicated by the European Court of Human Rights, the analysis of the Court's practice is necessary for understanding the scope of Rule 39 of the Rules of Procedure in effect. At the same time, it is essential to draw attention and indicate factors influencing State's compliance with a decision on Rule 39 of the Rules of Procedure of the European Court of Human Rights.

Analysis of research and publications. The issue of indication Rule 39 of the Rules of Procedure of the European Court of Human Rights in cases under individual applications was highlighted in the works of such scholars as Mykola Gnatovskyy, Ganna Yudkivska, William Schabas, David Harris, Kanstantsin Dzehtsiarou, Michael O'Boyle, Yves Haeck, and others. Meanwhile, the case practice of the European Court of Human Rights has the greatest significance for research in the field of interim measures.

Main material of the research. When the European Court of Human Rights (hereinafter - the ECtHR or the Court) receives and examines applications - both individual and inter-State - the question of granting interim measures at the request of a party/concerned representative or of the Court's motion may be raised. Rule 39 of the Rules of Procedure of the ECtHR is an instrument for human rights protection that allows the Court to indicate interim measures to be taken by a party/parties in order to prevent further violations of human rights and fundamental freedoms guaranteed by the Convention for the Protection of Human Rights and Fundamental Freedoms (hereinafter - the ECHR or the Convention) as well as respective Protocols thereto. Under Rule 39 of the Rules of Procedure of the ECtHR, the Chamber or, where appropriate, the President of the Section or a duty judge [the President of the Court may appoint Vice-Presidents of Sections as duty judges to decide on requests for interim measures] may indicate to the parties any interim measure which they consider should be adopted in the interests of the parties or of the proper conduct of the proceedings ${ }^{3}$.

The case law of the European Court of Human Rights is fundamental for interim measures and points out the following practical aspects as to granting positive decisions under Rule 39 of the Rules of Procedure. According to p.104 of judgment in the case of Mamatkulov and Askarov v. Turkey (applications nos. 46827/99 and 46951/99), "although it [the European Court of Human Rights] does receive a number of requests for interim measures, in practice the Court applies Rule 39 only if there is

\footnotetext{
${ }^{1}$ Committee of Ministers of the Council of Europe (2006). Recommendation Rec of the Committee of Ministers to member States on the European Prison Rule <https://search.coe.int/cm/Pages/result_details.aspx?ObjectId=09000016809ee581> (2021, May, 11).

${ }^{2}$ United Nations (2015). The United Nations Standard Minimum Rules for the Treatment of Prisoners (the Nelson Mandela Rules) <https://undocs.org/A/RES/70/175> (2021, May, 11).

${ }^{3}$ European Court of Human Rights (2021). Rules of Procedure of the European Court of Human Rights <https://www.echr.coe.int/documents/rules_court_eng.pdf> (2021, May, 11).
} 
an imminent risk of irreparable damage"1. The indication of this criterium by the European Court of Human Rights was a principal step towards further examination requests on interim measures since such a risk's indicator with regard to human rights violation allows analyses whether or not an applicant is in the status of the victim. Existence of the mentioned risk is determined by the consideration of the conditions which an applicant is under. By way of illustration, according to p.79 of judgment in the case of Paladi v. Moldova (application no. 39806/05), "the Court notes that the applicant was in a serious condition which, as appeared from the documents available at the relevant time, put his health at immediate and irremediable risk. That risk was the very reason for the Court's decision to indicate the interim measure" ${ }^{2}$. In the context of this research, one should also pay attention to the following practical issue regarding Rule 39 of the Rules of Procedure that lies in the case practice of the ECtHR. According to p.105 of judgment in the case of Mamatkulov and Askarov v. Turkey (applications nos. 46827/99 and 46951/99), "in most cases, measures are indicated to the respondent Government, although there is nothing to stop the Court from indicating measures to applicants". Therefore, it should be noted that the Rules of Procedure of the European Court of Human Rights provide for basic provisions as to interim measures indication and implementation whereas the case practice extends and clarifies Rule 39 completing legal lacunas.

As the ECtHR's practice demonstrates, Rule 39 requests largely concern the right to life (Art.2 of the European Convention on Human Rights), the right not to be subjected to torture or inhuman treatment (Art.3) as well as, more rarely, the right to respect for private and family life (Art.8) and other rights guaranteed by the ECHR and relevant Protocols thereto. In this research we will focus on interim measures in cases of persons in detention and violations of human rights guaranteed by the Convention which lead to indication Rule 39 of the Rules of Procedure with regard to persons in detention, including the ones that arise in line with conditions of detention, access to appropriate medical treatment, obstruction of communication with a lawyer, relatives, etc.

The European Committee for the Prevention of Torture and Inhuman or Degrading Treatment or Punishment (hereinafter - the CPT) in its General Report 1993 stated the following. "An inadequate level of health care can lead rapidly to situations falling within the scope of the term "inhuman and degrading treatment"3. During its practice the European Court of Human Rights defined three elements need to be considered with regard to persons in detention who suffer from physical or mental medical condition during their stay in detention: (a) the prisoner's medical condition, (b) the adequacy of the medical care provided in detention, and (c) the advisability of maintaining the detention measure in view of the state of the prisoner's health ${ }^{4}$. Taking into account the mentioned three elements and, as a result, in the case of "an imminent risk of irreparable damage", the European Court of Human Rights may indicate such interim measures in the interest of applicants as providing appropriate conditions under an applicant`s circumstances, accessing health care and medical treatment, transferring an applicant to a specialized hospital, etc. Measures under Rule 39 of the Rules of Procedure can be illustrated by virtue of the following cases.

For instance, in the case of Kotsaftis v. Greece (application no. 39780/06) ${ }^{5}$ the applicant, Mr Ioannis Kotsaftis, was sentenced to 13 years and four months in prison as a result of trafficking in antiquities and drugs. In August 2003 he was suffering from cirrhosis of the liver caused by hepatitis B. The national court suspended the execution of the sentence and allowed Mr Kotsaftis to take treatments for four months at the hospital. After receiving leave, the applicant disappeared. More than two years later Mr Kotsaftis was detained and returned to prison. At that time the motion to suspend the execution of the sentence for health reasons was rejected. Mr Kotsaftis complained to the ECtHR of the conditions of his detention on account, in particular, of the lack of treatment appropriate to his medical condition. According to Rule 39 of the Rules of Procedure, the Court required Greece to transfer the applicant to a medical center so that he could

\footnotetext{
${ }^{1}$ European Court of Human Rights (2008). Case of Mamatkulov and Askarov v. Turkey (applications nos. $46827 / 99$ and 46951/99) <https://hudoc.echr.coe.int/eng\#\{"appno":["46827/99"],"itemid":["001-68183"]\}> (2021, May, 11).

${ }^{2}$ European Court of Human Rights (2009). Case of Paladiv. Moldova (application no. 39806/05) <https://hudoc.echr.coe.int/fre\#\{"itemid":["001-91702"]\}> (2021, May, 11).

${ }^{3}$ European Committee for the Prevention of Torture and Inhuman or Degrading Treatment or Punishment (1993).

General Report of the CPT <https://rm.coe.int/16806ce943> (2021, May, 11).

${ }^{4}$ European Court of Human Rights (2009). Case of Neshkov and Others v. Bulgaria (applications nos. 36925/10, 21487/12, 72893/12, 73196/12, 77718/12 and 9717/13) <https://hudoc.echr.coe.int/fre\#\{\%22itemid\%22:[\%22001-150771\%22]\}> (2021, May, 11).

${ }^{5}$ European Court of Human Rights (2008). Case of Kotsaftis v. Greece (application no. 39780/06). <https://hudoc.echr.coe.int/eng\#\{"itemid":["001-86957"]\}> (2021, May, 11).
} 
undergo all the necessary examinations and remain in hospital until doctors determine that he could be returned to prison without risking his life. The applicant was transferred to the gastroenterology and hepatology department of the hospital.

In the case of Bamouhammad v. Belgium (application no. 47687/13) the applicant, Farid Bamouhammad, suffered from Ganser syndrome or "prison psychosis" as a result of harsh conditions of detention and lasting displacement to various prisons. On November 26, 2014, under Rule 39 of the Rules of Procedure, the European Court of Human Rights requested Belgium to provide the applicant with appropriate medical treatment. On November 29, 2014, Mr Bamouhammad was admitted to the relevant specialized hospital ${ }^{2}$.

In the case of Salakhov and Islyamova v. Ukraine (application no. 28005/08) the first applicant, Mr Linar Irekovich Salakhov, was HIV positive. On November 20, 2007, Mr Salakhov was arrested by the police on suspicion of robbery. The applicant's HIV status was ignored by the authorities and adequate medical care was not provided. On June 16, 2008, Mr Salakhov requested the European Court of Human Rights to indicate to Ukraine, under Rule 39 of the Rules of Procedure, that the applicant should be hospitalised and treated as a matter of urgency. On June 17, 2008, the Court decided to grant the interim measures and to indicate that Mr Salakhov "should be transferred immediately to a hospital or other medical institution where he [could] receive the appropriate treatment for his medical condition until further notice" ${ }^{3}$. On June 20, 2008, three days later, Mr Salakhov was taken to the AIDS Center. On August 1, 2008, the police lifted the security measures and the applicant was released. On August 2, 2008 he died from AIDS.

The abovementioned demonstrates that Rule 39 of the Rules of Procedure indicates, in particular, for putting into effect the widely accepted practice and standards as to person in detention in case of violation. Taking into account that there is a state responsibility to provide health care for prisoners with the same standards that are available in the community without discrimination on the grounds of their legal status $^{4}$, Rule 39 may serve, on the one hand, as an instrument of human rights protection in cases of a high urgency considering the special nature of the interim measures, on the other hand, as an instrument for drawing States`attention to problems in places of detention. Failure to comply with Rule 39 of the Rules of Procedure in terms of delivering adequate medical care may further be assessed by the European Court of Human Rights as treatment contradictory to Art.3 of the European Convention on Human Rights.

It should be noted that interim measures under Rule 39 of the Rules of Procedure of the Court may also be indicated in respect to an applicant if his/her action carries a threat. A difficult situation arises when a person in detention has declared a hunger strike. In such cases, authorities should avoid the punitive and inflexible approach towards detainees as well as be on track to dialogue and persuasion. The European Court of Human Rights in case practice emphasized that a "measure which was considered to be medically necessary - such as force-feeding a detainee to save her/his life - could not in principle be regarded as inhuman and degrading". At the same time, force-feeding has to be proved to be medically necessary and procedural guarantees should be complied with. As the following cases demonstrate, the European Court of Human Rights can also play its role under rare circumstances inviting an applicant in detention to end his/her hunger strike.

For instance, in the case of Rodić and 3 others v. Bosnia and Herzegovina (application no. 22893/05) ${ }^{6}$ the applicants were detained in Mostar Prison in Bosnia and Herzegovina. They were convicted of war crimes perpetrated against Bosniac civilians during the 1992-1995 war in Bosnia and Herzegovina. In cells the prisoners were subjected to persecution by their fellow prisoners because of the nature of their offence.

\footnotetext{
${ }^{1}$ Ganser syndrome is a rare dissociative disorder characterized by nonsensical or wrong answers to questions and other dissociative symptoms such as fugue, amnesia or conversion disorder, often with visual pseudohallucinations and a decreased state of consciousness. Whitlock, F.A. (1967). The Ganser Syndrome. The British Journal of Psychiatry, 113(494), 19-29. DOI: 10.1192/bjp.113.494.19.

${ }^{2}$ European Court of Human Rights (2008). Case of Bamouhammad v. Belgium

<https://hudoc.echr.coe.int/eng\#\{"itemid":["001-158750"]\}> (2021, May, 11).

${ }^{3}$ European Court of Human Rights (2013). Case of Salakhov and Islyamova v. Ukraine (application no. 28005/08) <https://hudoc.echr.coe.int/fre\#\{"itemid":["001-117134"]\}> (2021, May, 11).

${ }^{4}$ United Nations (2015). The United Nations Standard Minimum Rules for the Treatment of Prisoners (the Nelson

Mandela Rules)/ United Nations <https://undocs.org/A/RES/70/175> (2021, May, 11).

${ }^{5}$ European Court of Human Rights (2005). Case of Nevmerzhitsky v. Ukraine

<https://hudoc.echr.coe.int/fre\#\{"itemid":["002-3914"]\}> (2021, May, 11).

${ }^{6}$ European Court of Human Rights (2008). Case of Rodić and 3 others v. Bosnia and Herzegovina.

<https://hudoc.echr.coe.int/eng\#\{"itemid":["001-86533"]\}> (2021, May, 11).
} 
On June 8,2005 , the applicants declared a hunger strike in order to attract public attention to their situation. They were immediately placed in the Zenica Prison hospital unit. On June 24, 2005 (in respect of Mr Rodić), and on June 29, 2005 (in respect of the three other applicants), the European Court of Human Rights decided, under Rule 39 of the Rules of Court, to invite the applicants to discontinue their hunger strike. On July 1 , 2005, the applicants complied with the interim measures under Rule 39.

In the case of Ilaşcu and others v. Moldova and Russia (application no.48787/99) the application mainly concerns acts committed by the authorities of the "Moldavian Republic of Transdniestria". The applicants submitted that they had been convicted by a Transdniestrian court which was not competent for the purposes of Art.6 of the European Convention on Human Rights, that they had not had a fair trial and that following their trial they had been deprived of their possessions in breach of Art.1 of Protocol No.1. They further contended that their detention in Transdniestria was not lawful and that their conditions of detention contravened Art.3 and Art. 8 of the Convention. In addition, Mr Ilaşcu alleged a violation of Art.2 of the Convention on account of the fact that he had been sentenced to death. As a sign of protest, Mr Ivanţoc, one of the applicants, started a hunger strike. On January 15, 2004, the European Court of Human Rights decided to urge Mr Ivanţoc under Rule 39 to call off his hunger strike. On January 24, 2004, Mr Ivanţoc's representative informed the Court that his client had ended his hunger strike on January 15, $2004^{1}$.

In the case of Rappaz v. Switzerland (application no. 73175/10) ${ }^{2}$ the applicant was sentenced on October 22, 2008, to five years and eight months' imprisonment for various offences. On March 20, 2010, he began serving his sentence and embarked on a hunger strike protesting against his sentence, which in his view was excessively harsh. Then the applicant applied for release, arguing that his health was at risk, and he also requested the European Court of Human Rights to secure his release on the basis of Rule 39 of the Rules of Procedure. On December 15, 2010, the Court denied the request for interim measures and asked the applicant to end his hunger strike. On December 24, 2010, Mr Rappaz ended his hunger strike.

The abovementioned cases demonstrate that in circumstances where applicant's action carries a selfthreat, measures granted according to Rule 39 may serve as an instrument of lifesaving. At the same time, the issue of balance between force-feeding and medical necessity should be borne in mind and play a key role in this case. Since, according to the Court's practice, force-feeding could amount to torture within the meaning of Art.3, if there was no medical necessity.

As it is mentioned in the United Nations Standard Minimum Rules for the treatment of prisoners, "prisoners should have access to effective legal aid"3 (Rule 61). Furthermore, according to the mentioned Rule 61 of the Nelson Mandela Rules, "prisoners shall be provided with adequate opportunity, time and facilities to be visited by and to communicate and consult with a legal adviser of their own choice or a legal aid provider, without delay, interception or censorship and in full confidentiality, on any legal matter, in conformity with applicable domestic law" ${ }^{4}$. In some cases where there is a deep concern, the European Court of Human Rights may request a government to ensure that an applicant - in particular, a person in detention - has appropriate access to all available means of legal aid.

For instance, in the case of Öcalan v. Turkey (application no. 46221/99) the applicant, Mr Abdullah Öcalan, alleged, in particular, that he faced the restriction on the number and length of the meetings with his lawyers. Moreover, Mr Öcalan stated that he was not given proper access to any documents in the case file. On March 4, 1999, the European Court of Human Rights requested Turkey to take interim measures under Rule 39 of the Rules of Procedure and ensure that "the requirements of Article 6 [of the European Convention for Human Rights] were complied with in proceedings which had been instituted against the applicant in the National Security Court and that the applicant was able to exercise his right of individual application to the Court effectively through lawyers of his own choosing" " 5 . On March 23, 1999, the ECtHR invited Turkey to clarify specific points concerning the measures that had been taken pursuant to Rule 39 of

\footnotetext{
${ }^{1}$ European Court of Human Rights (2004). Case of Ilaşcu and others v. Moldova and Russia (application no.48787/99) <https://hudoc.echr.coe.int/eng\#\{"itemid":["001-61886"]\}> (2021, May, 11).

${ }^{2}$ European Court of Human Rights (2010). Case of Rappaz v. Switzerland (application no. 73175/10)

<https://hudoc.echr.coe.int/eng\#\{"itemid":["001-118757"]\}> (2021, May, 11).

${ }^{3}$ United Nations (2015). The United Nations Standard Minimum Rules for the Treatment of Prisoners (the Nelson Mandela Rules) <https://undocs.org/A/RES/70/175> (2021, May, 11).

${ }^{4}$ Ibid.

${ }^{5}$ European Court of Human Rights (2005). Case of Öcalan v. Turkey (application no. 46221/99).

<https://hudoc.echr.coe.int/fre\#\{"itemid":["001-69022"]\}> (2021, May, 11).
} 
the Rules of Procedure to ensure that the applicant had a fair trial. On April 9, 1999, the representative of Turkey to the Council of Europe stated that the Government was not prepared to reply to the Court's questions, as they went far beyond the scope of interim measures within the meaning of Rule 39.

The practice of the Court also contains examples of indication Rule 39 of the Rules of Procedure in cases related to a death penalty. In the case of Al-Saadoon \& Mufdhi v. the United Kingdom (application no. 61498/08) the applicants, Faisal Attiyah Nassar Khalaf Hussain Al-Saadoon and Khalef Hussain Mufdhi, were accused of being involved in the murder of two British soldiers. In December 2005 the Iraqi criminal courts decided that the allegations against the applicants constituted war crimes and therefore fell within the jurisdiction of the Iraqi High Tribunal (a court set up under Iraqi national law, to try Iraqi nationals or residents accused of genocide, crimes against humanity and war crimes allegedly committed during the period 17 July 1968 to 1 May 2003). The Iraqi High Tribunal requested the British forces to transfer the applicants into its custody. Their transfer by the British authorities into Iraqi custody put them at real risk of execution by hanging. The applicants applied to the European Court of Human Rights for an interim measure to prevent the British authorities making the transfer. On December 30, 2008, the European Court of Human Rights indicated to the UK government that the applicants should not be removed or transferred from their custody until further notice. The following day the UK Government informed the Court that, principally because the UN Mandate, which authorized the role of British forces in arrest, detention and imprisonment tasks in Iraq, was due to expire at midnight on 31 December 2008, exceptionally they could not comply with the measure indicated by the Court and that they had transferred the applicants to Iraqi custody earlier that day ${ }^{1}$. It should be noted that the European Court of Human Rights in its final decision on the merits has prohibited the death penalty under the European Convention on Human Rights.

In the abovementioned case of Öcalan v. Turkey (application no. 46221/99) the Turkish Court sentenced Mr Abdullah Öcalan to the death penalty on June 29, 2020. On November 30, 1999, the European Court of Human Rights granted interim measures in response to the request of one of the applicant's representatives for indication Rule 39 of the Rules of Procedure of the European Court of Human Rights. "The Court requests the respondent State to take all the necessary steps to ensure that the death penalty is not carried out so as to enable the Court to proceed effectively with the examination of the admissibility and merits of the applicant's complaints under the Convention"'2. Turkey had complied with the decision on Rule 39 of the Rules of Procedure. On October 3, 2002, Ankara State Security Court commuted the applicant's death sentence to life imprisonment.

In the context of the decision on Rule 39 of the Rules of Procedure under application no. 4743/21 Navalny v. Russia dated February 17, 2021, special attention should be given to such interim measures as the release of the applicant. The decision is unique since the European Court of Human Rights for the first time ever granted such interim measures. It should be noted that previously there were requests for indication as an interim measure under Rule 39 of the Rules of Procedure the release of an applicant. However, the European Court of Human Rights has absolutely refrained from granting such measures (see Savchenko v. Russia (application no. 50171/14), Özakça v. Turkey (application no. 45940/17), Gülmen v. Turkey (application no. 46171/17), and others).

In the case of Navalnyy v. Russia (application no. 4743/21) the applicant's representative requested the European Court of Human Rights to indicate interim measures under Rule 39 of the Rules of Procedure and release Mr Navalny from detention. The ECtHR made an information inquiry and asked the Government of the Russian Federation about the conditions of detention and the treatment, as well as safeguard measures. On January 26, 2021, Russia replied the following. "The applicant was being held in a properly guarded facility and his cell was under video surveillance. They described the material conditions in the cell and stated that the applicant had access to electronic communications via the prison system. He was allowed to make phone calls and had been visited by his lawyers and members of the public monitoring commission on several occasions"3. On February 3, 2021, the applicant submitted his comments

\footnotetext{
${ }^{1}$ European Court of Human Rights (2005). Case of Al-Saadoon \& Mufdhi v. the United Kingdom (application no. 61498/08). <https://hudoc.echr.coe.int/fre\#\{"itemid":["003-3044411-3369175"]\}> (2021, May, 11).

${ }^{2}$ European Court of Human Rights (2005). Case of Öcalan v. Turkey (application no. 46221/99). <https://hudoc.echr.coe.int/fre\#\{"itemid":["001-69022"]\}> (2021, May, 11).

${ }^{3}$ European Court of Human Rights (2021). Case of Navalny v. Russia (application no. 4743/21). <https://www.coe.int/en/web/portal/-/european-court-of-human-rights-asks-russia-to-release-aleksey-navalnyy> (2021, May, 11).
} 
to the Government's reply. He contested that the arrangements listed by the Government could not provide sufficient safeguards for his life and health. On February 16, 2021, the European Court of Human Rights decided to indicate to the Government of Russia, under Rule 39 of the Rules of Court, to release the applicant. Mr Navalny was not released and as a result the Russian Federation failed to comply with the decision on Rule 39 of the Rules of Procedure of the European Court of Human Rights. It is worth emphasizing that the decision has set a precedent and therefore it lifts up a wide range of questions - in particular, where a red line is, which consequences this decision leads to, whether the State will comply with this decision.

Taking into account the abovementioned, the issue of the legal force of the decision on interim measures under Rule 39 of the Rules of Procedure should be analyzed. The Rules of Procedure of the European Court of Human Rights do not strictly provide for a legally binding nature of interim measures under Rule 39 of the Rules of Procedure that, in turn, has created a field for discussion.

As it was mentioned earlier, the case practice is crucial for interim measures as well as, in particular, forms the basis for determining the legal force of Rule 39 of the Rules of Procedure of the European Court of Human Rights. The Court, by the means of its decisions, has indicated a legally binding force of granted interim measures. In particular, the case of Mamatkulov and Askarov v.Turkey (application no. 46827/99) is a key case as to the legal force of interim measures under Rule 39 of the Rules of Procedure where the Court indicated the following.

"The fact that the respondent Government failed to comply with the measures indicated by the Court under Rule 39 of the Rules of Court raises the issue of whether the respondent State is in breach of its undertaking under Article 34 of the Convention not to hinder the applicants in the exercise of their right of individual application" (p.99) ${ }^{1}$.

The ECtHR has systematically pointed to the close nexus between Rule 39 of the Rules of the Court and Art. 34 of the European Convention on Human Rights (see also p.80 of the case Olaechea Cahuas v. Spain (application no. 24668/03). Moreover, in p. 111 of the case Aoulmi v. France (application no. 50278/99) the European Court of Human Rights stated the following. "The Court reiterates that by virtue of Article 34 of the Convention Contracting States undertake to refrain from any act or omission that may hinder the effective exercise of an individual applicant's right of application. It stresses that, in the present case, even though the binding nature of measures adopted under Rule 39 had not yet been expressly asserted at the time of the applicant's expulsion, Contracting States were nevertheless already required to comply with Article 34 and fulfil their ensuing obligations" ${ }^{2}$.

At the same time, it should be noted that the Rules of Procedure of the European Court of Human Rights provide for that "the Chamber or, where appropriate, the President of the Section or a duty judge may request information from the parties on any matter connected with the implementation of any interim measure indicated" ${ }^{3}$. Therefore, the European Court of Human Rights reserves the right to monitor the implementation by a party or parties of certain measures. Although the binding nature of decisions on the application of Rule 39 is not expressly enshrined in the Rules of Procedure, the ECtHR presupposes that the party or parties to the case will comply with the decision on interim measures.

In cases where a State fails to comply with a decision to apply Rule 39 of the Rules of the Court, the ECtHR may apply to that State to take certain interim measures. For example, in the case of Savriddin Dzhurayev v. Russia (application no. 71386/10), the European Court of Human Rights, after being informed that the Russian Federation had not complied with the indicated interim measures, called on the State to take positive measures to enforce the decision under Rule 39.

In the study "The European Convention on Human Rights: A Commentary", William Schabas refers to the disregard by States of decisions on the application of Rule 39 of the Rules of Procedure of the European Court of Human Rights. "Nevertheless, some governments continue to defy the Court's indication of interim measures. In 2013, Russia contented that the legally binding force of the interim measure issued under Rule 39 of the Rules of Court may not be drawn from Article 34 of the Convention or

\footnotetext{
${ }^{1}$ European Court of Human Rights (2005). Case of Mamatkulov and Askarov v. Turkey (applications nos. $46827 / 99$ and 46951/99) <https://hudoc.echr.coe.int/eng\#\{ "appno":["46827/99"],"itemid":["001-68183"]\}> (2021, May, 11).

${ }^{2}$ European Court of Human Rights (2006). Case Aoulmi v. France (application no. 50278/99).

<https://www.refworld.org/cases,ECHR,45cc89d52.html> (2021, May, 11).

${ }^{3}$ European Court of Human Rights (2021). Rules of Procedure of the European Court of Human Rights.

<https://www.echr.coe.int/documents/rules_court_eng.pdf> (2021, May, 11).
} 
from any other source. Moreover, it said that the Rules of Procedure and accordingly the interim measure applied did not have a binding force on the State Party... In 2008, the United Kingdom did not comply with interim measures of the Court when it transferred two detainees to the Iraqi authorities, although there was a threat that they would be subject to capital punishment. An indication under Rule 39 could not require a Contracting State to violate the law and sovereignty of a non-Contracting State, the United Kingdom claimed, insisting that it was required to make the transfer under Iraqi law. It said the case was exceptional because the facts arose outside of its own territory, noting that the United Kingdom government were proud of their long history of cooperation with the Court and their compliance with previous Rule 39 indications. They had failed to comply with the indication" ${ }^{1}$. Thus, the practice of enforcing decisions of the European Court of Human Rights on interim measures shows that states decide on the binding nature of such measures at their own discretion guided by their own interests. The lack of legal binding nature of such decisions in the documents of the ECtHR, and hence an effective mechanism for responding to noncompliance with decisions on interim measures, significantly mitigates the nature of this instrument of human rights protection.

One should pay attention that it is common practice among states to refer to the existence of objective obstacles to the timely implementation of decisions of the European Court of Human Rights. However, in the case of Paladi v. Moldova (application no. 39806/05), the European Court of Human Rights noted that the untimely execution of a decision to apply an interim measure is a violation of Art. 34 of the European Convention on Human Rights. According to Professor Clara Burbano Herrera and Professor Yves Heck, late implementation of the decision to apply interim measures is a violation of the European Convention on Human Rights, unless the State proves the following:

1) the actual existence of objective obstacles;

2) the State has taken appropriate steps to eliminate such obstacles;

3) the State informed the European Court of Human Rights about the existence of such obstacles ${ }^{2}$.

Interim measures' nature presupposes both extraordinary examination of relevant request on indication of such measures and its timely execution by the Party concerned. Only in such a way the interim measures make sense. Otherwise, failing to comply with a decision on interim measures weakens and devaluates the meaning of interim measures for human rights protection. At the same time, the will of the State to conform with indicated measures is a principal issue for their implementation and further playing its role.

Conclusion. Rule 39 of the Rules of Procedure of the European Court of Human Rights in cases of persons in detention indicates while an urgent situation takes place and a person faces "an imminent risk of irreparable damage", i.e. a person faces a real risk for his/her health or even life. In such cases interim measures play a role of a human rights protection instrument which aimed at putting into action the widely accepted best practices and standards as to treatment of persons in detention. Taking into account that there is a state responsibility to provide that all persons deprived of their liberty shall be treated with respect for their human rights without discrimination on the grounds of their legal status, Rule 39 of the Rules of Procedure is also used as a flag to States which emphasized the following aim - do not cross a red line in human rights dimension.

Indicated interim measures in cases of persons in detention invariably presuppose a return to the respect of human rights and fundamental freedoms. At the same time, a fair balance between respect for the rights and freedoms of the individual and her/his legal status is needed.

The issue of compliance with a decision on Rule 39 of the Rules of Procedure raises the question of the binding nature of such measures. The Court practice demonstrates that the binding nature of interim measures arises from the States` necessity to fulfil their ensuing obligations under Art.34 of the Convention for the Protection of Human Rights and Fundamental Freedoms. At the same time, the will of the High Contracting Parties to fulfil their obligations under the European Convention on Human Rights and the relevant Protocols thereto play a key role in the context of interim measures. Since States may also refer to

\footnotetext{
${ }^{1}$ Schabas, W. (2015). The European Convention on Human Rights: A Commentary. Oxford: Oxford Commentaries on International Law <https://opil.ouplaw.com/view/10.1093/law/9780199594061.001.0001/law-9780199594061> (2021, May, 11).

${ }^{2}$ Burbano-Herrera, C., Haeck, Y. (2010). "Letting States off the Hook? The Paradox of the Legal Consequences Following State Non-Compliance with Provisional Measures in the Inter-American and European Human Rights Systems". Netherlands Quarterly of Human Rights, 28/3, 353.
} 
the existence of objective obstacles to the timely implementation of decisions of the European Court of Human Rights. Meanwhile, a State`s failure to comply with a decision on interim measures significantly influences the role of interim measures for human rights protection.

\section{References:}

1. Burbano-Herrera, C., Haeck, Y. (2010). "Letting States off the Hook? The Paradox of the Legal Consequences Following State Non-Compliance with Provisional Measures in the Inter-American and European Human Rights Systems". Netherlands Quarterly of Human Rights, 28/3, 332-360. [in English].

2. Committee of Ministers of the Council of Europe (2006). Recommendation Rec of the Committee of Ministers to member States on the European Prison Rule $<$ https://search.coe.int/cm/Pages/result_details.aspx?ObjectId=09000016809ee581> (2021, May, 11). [in English].

3. European Committee for the Prevention of Torture and Inhuman or Degrading Treatment or Punishment (1993). General Report of the CPT <https://rm.coe.int/16806ce943> (2021, May, 11). [in English].

4. European Court of Human Rights (2004). Case of Ilaşcu and others v. Moldova and Russia (application no.48787/99) <https://hudoc.echr.coe.int/eng\#\{"itemid":["001-61886"]\}> (2021, May, 11). [in English].

5. European Court of Human Rights (2005). Case of Al-Saadoon \& Mufdhi v. the United Kingdom (application no. 61498/08). <https://hudoc.echr.coe.int/fre\#\{"itemid":["003-3044411-3369175"]\}> (2021, May, 11). [in English].

6. European Court of Human Rights (2005). Case of Mamatkulov and Askarov v. Turkey (applications nos. 46827/99 and 46951/99) <https://hudoc.echr.coe.int/eng\#\{"appno":["46827/99"],"itemid":["001-68183"]\}> (2021, May, 11). [in English].

7. European Court of Human Rights (2005). Case of Nevmerzhitsky v. Ukraine <https://hudoc.echr.coe.int/fre\#\{"itemid":["002-3914"]\}> (2021, May, 11). [in English].

8. European Court of Human Rights (2005). Case of Öcalan v. Turkey (application no. 46221/99). <https://hudoc.echr.coe.int/fre\#\{"itemid":["001-69022"]\}> (2021, May, 11). [in English].

9. European Court of Human Rights (2005). Case of Öcalan v. Turkey (application no. 46221/99). $<$ https://hudoc.echr.coe.int/fre\#\{"itemid":["001-69022"]\}> (2021, May, 11). [in English].

10. European Court of Human Rights (2006). Case Aoulmi v. France (application no. 50278/99). <https://www.refworld.org/cases,ECHR,45cc89d52.html> (2021, May, 11). [in English].

11. European Court of Human Rights (2008). Case of Bamouhammad v. Belgium <https://hudoc.echr.coe.int/eng\#\{"itemid":["001-158750"]\}> (2021, May, 11). [in English].

12. European Court of Human Rights (2008). Case of Kotsaftis v. Greece (application no. 39780/06). <https://hudoc.echr.coe.int/eng\#\{"itemid":["001-86957"]\}> (2021, May, 11). [in English].

13. European Court of Human Rights (2008). Case of Mamatkulov and Askarov v. Turkey (applications nos. 46827/99 and 46951/99) <https://hudoc.echr.coe.int/eng\#\{ "appno":["46827/99"],"itemid":["001-68183"]\}> (2021, May, 11). [in English].

14. European Court of Human Rights (2008). Case of Rodić and 3 others v. Bosnia and Herzegovina. <https://hudoc.echr.coe.int/eng\#\{"itemid":["001-86533"]\}> (2021, May, 11). [in English].

15. European Court of Human Rights (2009). Case of Neshkov and Others v. Bulgaria (applications nos. 36925/10, 21487/12, 72893/12, 73196/12, 77718/12 and 9717/13) <https://hudoc.echr.coe.int/fre\#\{\%22itemid\%22:[\%22001$150771 \% 22]\}>(2021$, May, 11). [in English].

16. European Court of Human Rights (2009). Case of Paladi v. Moldova (application no. 39806/05) <https://hudoc.echr.coe.int/fre\#\{"itemid":["001-91702"]\}> (2021, May, 11). [in English].

17. European Court of Human Rights (2010). Case of Rappaz v. Switzerland (application no. 73175/10) <https://hudoc.echr.coe.int/eng\#\{"itemid":["001-118757"]\}> (2021, May, 11). [in English].

18. European Court of Human Rights (2013). Case of Salakhov and Islyamova v. Ukraine (application no. 28005/08) <https://hudoc.echr.coe.int/fre\#\{"itemid":["001-117134"]\}> (2021, May, 11). [in English].

19. European Court of Human Rights (2021). Case of Navalny v. Russia (application no. 4743/21). <https://www.coe.int/en/web/portal/-/european-court-of-human-rights-asks-russia-to-release-aleksey-navalnyy> (2021, May, 11). [in English].

20. European Court of Human Rights (2021). Rules of Procedure of the European Court of Human Rights <https://www.echr.coe.int/documents/rules_court_eng.pdf> (2021, May, 11). [in English].

21. Schabas, W. (2015). The European Convention on Human Rights: A Commentary. Oxford: Oxford Commentaries on International Law <https://opil.ouplaw.com/view/10.1093/law/9780199594061.001.0001/law-9780199594061> (2021, May, 11). [in English].

22. United Nations (2015). The United Nations Standard Minimum Rules for the Treatment of Prisoners (the Nelson Mandela Rules) <https://undocs.org/A/RES/70/175> (2021, May, 11). [in English].

23. Whitlock, F.A. (1967). The Ganser Syndrome. The British Journal of Psychiatry, 113(494), 19-29. DOI: 10.1192/bjp.113.494.19. [in English]. 